\title{
Datura innoxia Mill. (Solanaceae), a new alien species in the flora of Bosnia and Herzegovina
}

\author{
Semir Maslo ${ }^{1} \&$ Šemso Šarić ${ }^{2}$ \\ ${ }^{1}$ Primary School, Lundåkerskola, Gislaved, Sweden; semmas@edu.gislaved.se \\ Jelaške, Olovo, Bosnia and Herzegovina; semsosumar@gmail.com
}

Maslo, S. \& Šarić, Š. (2019): Datura innoxia Mill. (Solanaceae), a new alien species in the flora of Bosnia and Herzegovina. - Thaiszia - J. Bot. 29 (2): 225-230

Abstract: Downy thorn-apple Datura innoxia Mill is native in southwest U.S.A. and Mexico. It has been recorded as a new alien species to the vascular flora of Bosnia and Herzegovina. In Bosnia and Herzegovina, $D$. innoxia is reported from two localities in the city of Mostar where the species has escaped cultivation and established small populations in surrounding ruderal habitats including waste land. The species is toxic to animals and humans. The paper presents a short morphological characteristic and photographs as well as the distribution of the species in the Bosnia and Herzegovina.

Keywords: alien plants, Bosnia and Herzegovina, Datura, distribution, garden escape, morphology.

\section{Introduction}

The genus Datura L. belongs to the tribe Datureae G. Don, of Solanaceae. There are about 10 species which occur naturally in south-western USA and Mexico, and parts of Central America (Dupin \& Smith 2018). Within the genus Datura, only six species have been recorded as escapees in Europe of which four have been reported in the Balkans: Datura ferox L., Datura innoxia Mill., Datura metel L. and Datura stramonium L. (Valdés 2012).

To identify this new alien species, we present an adjusted key to the species of Datura in Balkans, based on Haegi (1976), Child \& Shaw (1999) and Shaw (2000). 
1 Capsule deflexed, breaking irregularly when ripe; leaves entire, repand, sinuate or singly lobed; seeds brown or yellowish

1 Capsule erect, breaking regularly into 4 entire valves when ripe; leaves doubly lobed; seeds black

3

2 Capsule with numerous short blunt tubercles; corolla white, purple or yellow, normally 5 -lobed; plants hairless or sparsely hairy with simple hairs only .D. metel

2 Capsule with numerous slender sharp spines; corolla white, normally 10-lobed; plants densely velvety hairy with glandular hairs D. innoxia

3 Capsule with more than 100 spines of similar length D. stramonium

3 Capsule with fewer than 60 spines of unequal length D. ferox

Datura innoxia Mill. (syn. Datura meteloides Dunal), also known as Downy thorn-apple and its native range is from south-western USA and Mexico, through Central America to northern and western South America (CABI 2018). Occasionally grown as an ornamental plant in gardens, this species now has a wide distribution in the warmer parts of both hemispheres. The species is a rare garden escapee, occasionally naturalised on dumps or as a remnant of cultivation in some parts of the European continent (CABI 2018). The aim of the article is to report the first record of the species in the flora of Bosnia and Herzegovina.

\section{Material and methods}

The field study was conducted in the summer of 2018 and 2019. Digital photographs and GPS coordinates were taken in the field. The identification of the specimens was done according to Haegi (1976), Hammer et al. (1983), Child \& Shaw (1999) and Shaw (2000). The nomenclature follows Valdés (2012). The voucher specimen is deposited in the Herbarium of the National Museum of Bosnia and Herzegovina (SARA, 51983).

\section{Results and discussion}

Datura innoxia is a stout, annual to perennial herb to up to $2 \mathrm{~m}$ high, with swollen taproot, and a spreading crown up to $2 \mathrm{~m}$ in diameter. Stems with dense, spreading glandular hairs. Mature leaves broadly ovate, the lamina up to $20 \mathrm{~cm}$ long, almost entire, slightly sinuate, or irregularly lobed towards the base. Inflorescence of solitary, bisexual flowers in the bifurcations of the branches; peduncles about $10 \mathrm{~mm}$, stout. Calyx 5-10 cm long, narrowly cylindrical, 3-6-lobed; lobes 13-20 mm long, sometimes incompletely separated. Corolla white with green veins, infundibuliform, with a tube $15-16 \mathrm{~cm}$ long, spreading gradually towards the apex and terminating in 10 small, subulate lobes. Stamens not exerted; anthers 8-10 mm long. Style 10-14 cm long; stigma well below anthers. The fruit is a globose or ovoid spiny capsule with numerous slender spines, about 3-5 cm in diameter, deflexed, spiny; spines numerous, slender, sharp, all about equal in length, to $10 \mathrm{~mm}$ long; persistent base of calyx to $20 \mathrm{~mm}$ long, very prominent. Capsule breaking irregularly when ripe, releasing brown seeds. Seeds D-shaped, compressed, 4-5 mm long (Fig. 1), (adapted from Haegi 1976 and Sell \& Murrell 2009). 

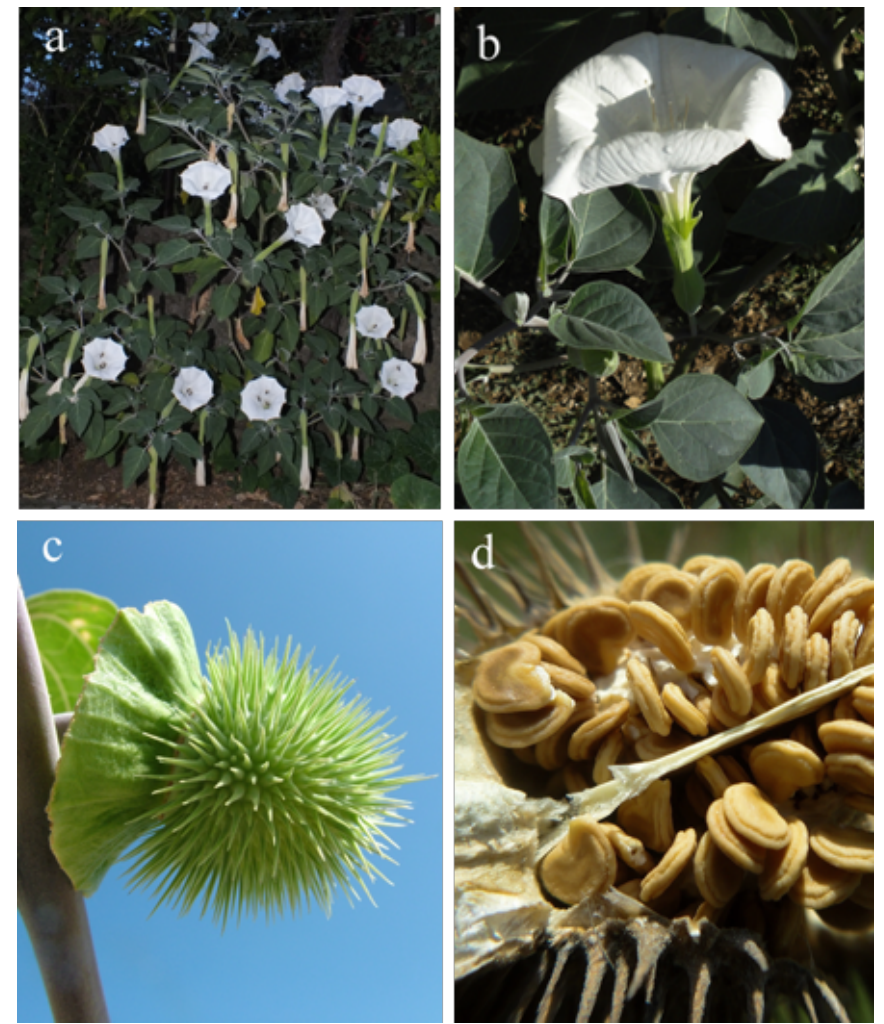

Fig. 1. Datura innoxia Mill. in the Bosnia and Herzegovina: $a-$ habitat $b-$ flower $\mathrm{c}-$ capsule $\mathrm{d}-$ seeds (Photos a, c by S. Maslo; b, d by Š. Šarić)

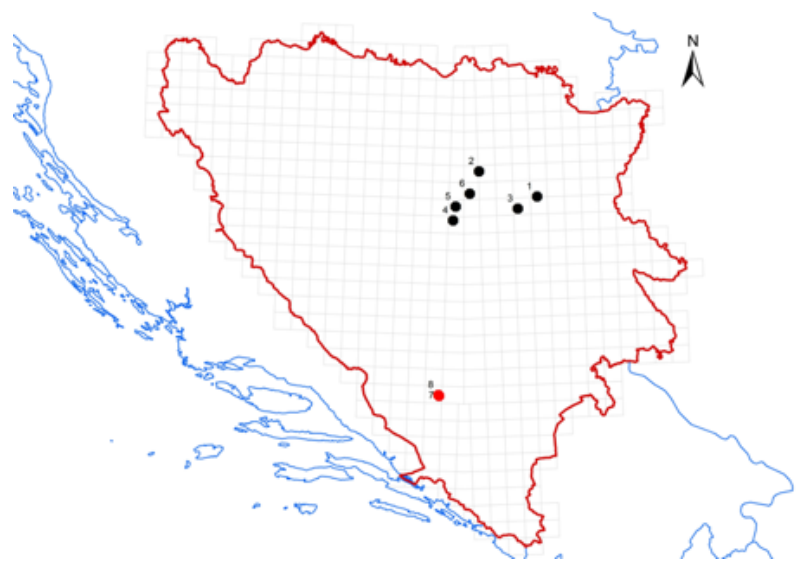

Fig. 2.The distribution of Datura innoxia Mill. in the Bosnia and Herzegovina. Cultivated plants (black dots) and plants escaped from cultivation (red dot). 
Based on our field studies, we have found that D. innoxia is also present in Bosnia and Herzegovina, both as cultivated ornamental plant, but as well as an escape. We have registered this species in eight localities in Central Bosnia and Southern Herzegovina of which two relate to plants that have escaped from cultivation (Fig. 2). In Bosnia and Herzegovina, this species as escaped from cultivation was first registered in 2018. Two individuals of $D$. innoxia were found in the city of Mostar, in the area of Sjeverni logor, on slopes of waste and soil piles near the newly built bridge over the Neretva River. Another record of $D$. innoxia was made on the rubbish tips in the Mostar's quarter Pasjak in 2019. Three individuals were recorded and two of these were large, well-developed individuals with ripening fruits.

\section{Recent chorological data on cultivation and garden escaping}

\section{Central Bosnia:}

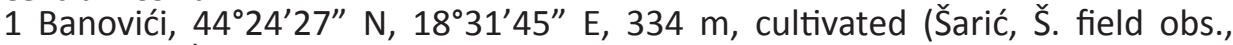
08.2018)

2 Maglaj, cemetery, $44^{\circ} 32^{\prime} 32^{\prime \prime}$ N, 1806'02" E, 191 m, cultivated (Šarić, Š. field obs., 08.2018)

3 Zavidovići - Ribnica, 4420'43” N, 18²3’35” E, 297 m, cultivated (Šarić, Š. field obs., 08.2018)

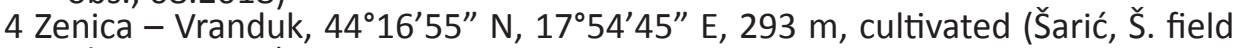
obs., 08.2018)

5 Zenica - Topčić polje, $44^{\circ} 21^{\prime} 23^{\prime \prime}$ N, 1756'15” E, 278 m, cultivated (Šarić, Š. field obs., 08.2018)

6 Žepče, $44^{\circ} 25^{\prime} 24^{\prime \prime}$ N, $18^{\circ} 02^{\prime} 27^{\prime \prime}$ E, 226 m, cultivated (Šarić, Š. field obs., 08.2018)

\section{South Herzegovina:}

7 Mostar - on the rubbish tips in the Mostar's quarter Pasjak, 43 $21^{\prime} 00^{\prime \prime} \mathrm{N}$, $17^{\circ} 48^{\prime} 50^{\prime \prime}$ E, $76 \mathrm{~m}$, escaped from cultivation (Maslo, S. field obs., 07.2019)

8 Mostar - Sjeverni logor, on slopes of waste and soil piles near the newly built bridge over the Neretva River, $43^{\circ} 21^{\prime} 28^{\prime \prime} \mathrm{N}, 17^{\circ} 48^{\prime} 32^{\prime \prime} \mathrm{E}, 62 \mathrm{~m}$, escaped from cultivation (Maslo, S. field obs., 07.2018)

Datura species are thought to spread solely by seed which it produces in large number. The seeds are distributed by ants and some species of birds that are resistant to the chemicals they contain. The way of introduction is unknown, probably from seeds, which got to dumps and disturbed areas with garden waste. In Bosnia and Herzegovina, this species currently is casual species and its establishment is highly possible. The potential invasive behavior of the species should be monitored in the following years.

In Europe, escaped populations of $D$. innoxia have mostly been found at roadsides and different types of ruderal habitats. It has been recorded in most countries of Southern and Central Europe as well as in some countries of Northern Europe: Austria (Essl \& Rabitsch 2002), Belgium (Verloove 2006), Bulgaria (Greuter \& Raus 2005), Croatia (Franjić 1993; Pandža \& Stančić 1999; Pandža et al. 2001), Czech Republic (Danihelka et al. 2012), European Turkey (Vladimirov et al. 2013), France (Kerguélen 1999), Great Britain (Sell \& Murrell 2009), Greece (Arianoutsou et al. 2010), Italy (Pignatti 1982), Lithuania (Gudžinskas 2017), 
Montenegro (Caković et al. 2014), Norway (Gederaas et al. 2012), Portugal (Almeida \& Freitas 2001), Romania (Anastasiu et al. 2011), Russia (Seregin 2014), Spain (Castroviejo et al. 2012), Serbia (Lakušić et al. 2017), Slovakia (Medvecká et al. 2012), Slovenia (Martinčič et al. 1999), Sweden (Karlsson 1997) and Ukraine (Mosyakin \& Fedoronchuk 1999). In the Mediterranean region D. innoxia has established, whereas in other regions it is ascribed to the group of casual species. According to Sanz et al. (2004) the species is referred to as invasive in France, Italy, Portugal and Spain as well as in Croatia (Boršić et al. 2008; Nikolić et al. 2009).

\section{Acknowledgements}

We would like to thank Aldin Boškailo (Mostar, Bosnia and Herzegovina) for mapping the distribution of the species and Lanna Maslo (Malmö, Sweden) for improving the English of this paper.

\section{References}

Almeida J. D. \& Freitas H. (2001): The exotic and invasive flora of Portugal. - Bot. Complutensis 25: 317-327.

Anastasiu P., Negrean G., Samoilă C., Memedemin D., Cogalniceanu D. (2011): A comparative analysis of alien plant species along the Romanian Black Sea coastal area. The role of harbours. - J. Coast. Conserv. 15/4: 595-606. DOI 10.1007/s11852011-0149-0.

Arianoutsou M., Bazos I., Delipetrou P. \& Kokkoris Y. (2010): The alien flora of Greece: taxonomy, life traits and habitat preferences. - Biol. Invasions 12/10: 3525-3549. https://doi.org/10.1007/s10530-010-9749-0.

Boršić I., Milović M., Dujmović I., Bogdanović S., Cigić P., Rešetnik I., Nikolić T., Mitić, B. (2008): Preliminary check-list of invasive alien plant species(ias) in Croatia. - Nat. Croat. 17/2: 55-71.

CABI (2018): Datura innoxia (downy thorn apple) [original text by Pasiecznik, N.]. - In: Invasive Species Compendium. Wallingford, UK: CAB International (www.cabi.org/ isc). [accessed September 2019].

Caković D., Stešević D., Vuksanović D. \& Tan K. (2014): Colchicum cupanii Guss. Subsp. Glossophyllum (Heldr.) Rouy, Datura innoxia Mill. And Eclipta prostrata (L.) L., new floristic records in Montenegro and western Balkan. - Acta Bot. Croat. Zagreb 73/1: 255-265. https://doi.org/10.2478/botcro-2013-0023.

Castroviejo B. S. \& al. (eds.) (2012): Flora Iberica 11. Gentianaceae-Boraginaceae. - Real Jardín Botánico, CSIC, Madrid. 672 pp.

Child A. \& Shaw J. M. H. (1999): Keys to Datura and Brugmansia (Solanaceae). - BSBI News 82: 54-57.

Danihelka J., Chrtek J. \& Kaplan Z. (2012): Checklist of vascular plants of the Czech Republic. - Preslia. 84/3: 647-811.

Dupin J. \& Smith S. D. (2018): Phylogenetics of Datureae (Solanaceae), including description of the new genus Trompettia and re-circumscription of the tribe. Taxon 67/2: 359-375. DOI: 10.12705/672.6

Essl F. \& Rabitsch W. (2002): Neobiota in Österreich. - Umweltbundesamt, Wien. 432 pp.

Franjić J. (1993): New localities of the species Datura innoxia Miller (Solanaceae) in Croatia. - Acta Bot. Croat. 52: 97-100. [In Croatian with an English summary] 
Gederaas L., Moen T. L., Skjelseth S. \& Larsen L. K. (eds.) (2012): Alien species in Norway - with the Norwegian Black List 2012. - Norwegian Biodiversity Information Centre. - Trondheim, Norway. $212 \mathrm{pp}$.

Greuter W. \& Raus T. (2005): Med-Checklist notulae 23. - Willdenowia (Berlin-Dahlem) 35: 55-64.

Gudžinskas Z. (2017): Alien herbaceous plant species new to Lithuania. - Bot. Lith. 23/1: 33-42. https://doi.org/10.1515/botlit-2017-0003

Haegi L. (1976): Taxonomic account of Datura L. In Australia with a note on Brugmansia Pers. - Austr. J. Bot. 24: 415-435. DOI:10.1071/bt9760415

Hammer K., Romeike A. \& Tittel C. (1983): Vorarbeiten zur monographischen Darstellung von Wildpflanzensortimenten: Datura L., sectiones Dutra Bernh., Ceratocaulis Bernh. Et Datura. - Kulturpflanze 31/1: 13-75. https://doi.org/10.1007/BF02000698

Karlsson T. (1987): The vascular plants of Sweden - a checklist. - Svensk Bot. Tidskr. 91: 241-560. - Lund. [In Swedish with English summary].

Kerguélen M. (1999): Index Synonymique de la Flore de France.

Lakušić D., Rat M., Anačkov G., Jovanović S. (2017): Datura inoxia Mill. (Solanaceae), a new alien species in Serbia. - Biol. Nyssana 8/1: 47-51. DOI: 10.5281/zenodo.963583

Martinčič A., Wraber T., Jogan N., Ravnik V., Podobnik A., Turk B. \& Vreš B. (1999): Small Flora of Slovenija. - Tehniška založba Slovenije, Ljubljana.

Medvecká J., Kliment J., Májeková J., Halada L'., Zaliberová M., Gojdičová E., Feráková V. \& Jarolímek I. (2012): Inventory of the alien flora of Slovakia. - Preslia 84/2: 257-309.

Mosyakin S. L. \& Fedoronchuk M. M. (1999): Vascular plants of Ukraine. A nomenclatural checklist.- M. G. Kholodny Institute of Botany, National Academy of Sciences of Ukraine.

Nikolić T., Mitić B. \& Boršić I. (2009): Flora Hrvatske: Invazivne biljke.- Alfa d.o.o. Zagreb. $295 \mathrm{pp}$.

Pandža M., Franjić J., Trinajstić I., Škvorc Z., Stančić Z. (2001): The most recent state of affairs in the distribution of some neophytes in Croatia. - Nat. Croat. 10/4: 259-275.

Pandža M. \& Stančić Z. (1999): New localities of the species Datura innoxia Miller and Solanum elaeagnifolium Cav. (Solanaceae) in Croatia. - Nat. Croat. 8/2: 117-124.

Pignatti S. (1982): Flora d'Italia 2. - Edagricole, Bologna, Italy. 732 pp.

Sanz Elorza M., Dana Sánchez E. D. \& Sobrino Vesperinas E. (eds.). (2004): Atlas de las Plantas Alóctonas Invasoras en España. - Dirección General para la Biodiversidad. Madrid, $384 \mathrm{pp}$.

Sell P. \& Murrell G. (2009): Flora of Great Britain and Ireland. Vol. 3 Mimosaceae Lentibulariaceae. - Cambridge University Press, Cambridge, UK. 624 pp.

Seregin A. P. (2014): Flora of Vladimir Oblast, Russia: grid data analysis - KMK schientific press, Moscow. 441 pp.

Shaw J. M. H. (2000): Datura. Pp. 247-248. - In: Cullen J. \& al. (eds.): The European Garden Flora. Vol. 6. - Cambridge University Press, Cambridge.

Valdés B. (2012): Solanaceae. - In: Euro+Med PlantBase - the information resource for Euro-Mediterranean plant diversity [accessed September 2019].

Verloove F. (2006): Catalogue of neophytes in Belgium (1800-2005). - Scripta Bot. Belg. 39. - Meise, National Botanic Garden of Belgium. 89 pp.

Vladimirov V., Dane F., Stevanović V. \& Tan K. (2013): New floristic records in the Balkans: 22 - Phytol. Balcan. 19/2: 267-303. 